\title{
An empirical analysis on the effects of marketing communications on market share adjustment
}

\author{
Somayeh Hozouri* and Mojgan pazuki
}

Department of Management, Islamic Azad University, South Tehran Branch, Tehran, Iran

\begin{tabular}{|c|c|}
\hline CHRON I C LE & A B S T RACT \\
\hline $\begin{array}{l}\text { Article history: } \\
\text { Received August } 25,2013 \\
\text { Received in revised format } \\
19 \text { September } 2013 \\
\text { Accepted } 23 \text { October } 2013 \\
\text { Available online } \\
\text { November } 122013 \\
\text { Keywords: }\end{array}$ & $\begin{array}{l}\text { During the past few years, there has been growing competition between two primary sources of } \\
\text { mobile service providers including Hamrah Aval and Irancell in Iran. The competition is so } \\
\text { tight that both service providers have spent significant amount of money on marketing } \\
\text { planning. Therefore, it is necessary to find important factors influencing on better marketing } \\
\text { planning. This paper presents an investigation to analyze the effects of marketing } \\
\text { communications on market share adjustment. The proposed study of this paper has used } \\
\text { principle component analysis and it has detected four factors environment issues, marketing } \\
\text { organization, market development and relationship oriented. }\end{array}$ \\
\hline
\end{tabular}

Factor analysis

Marketing planning

Mobile

\section{Introduction}

During the past few years, there has been growing competition between two primary sources of mobile service providers including Hamrah Aval and Irancell in Iran. The competition is so tight that both service providers have spent significant amount of money on marketing planning. These days, these two mobile providers sponsor most popular TV movies, people could see their promotion plans on different billboards located in high ways, subways, etc. Therefore, it is essential for such firms to find appropriate communication channels to penetrate into market, more efficiently and effectively so that not only retain their market share but also gain more market share. There are literally various methods for offering high quality products into the market. For years, many industries attempted to offer high quality products to attract more customers and gain more market share using various techniques such as build-to-order and lean manufacturing processes (Sharma \& LaPlaca, 2005; White \& Dieckman, 2005; Belch et al., 2008).

* Corresponding author. Tel.: +98 9125367924 
Market-based organizational learning has been recognized as a primary source of sustainable competitive advantage and benchmarking has been used as management tool for identifying and enhancing valuable marketing capabilities (Vorhies \& Morgan, 2005). Eid et al. (2006) provided some basis for further research and good practice in benchmarking by combining the best characteristics of traditional and new internet marketing activities. The multi-channel challenge is another important technique for penetrating into market (Wilson \& Daniel, 2007). Blois and Ramirez (2006) discussed different capabilities as marketable assets. Dutta et al. (2005) discussed conceptualizing and measuring capabilities by introducing a methodology and empirical application.

Payne and Frow (2005) developed a conceptual framework for customer relationship management (CRM) to investigate its role in enhancing customer value as well as shareholder value. They explored different characteristics of CRM, and identified three alternative perspectives of CRM. They also detected five key cross-functional CRM processes including a strategy development process, a value creation process, a multichannel integration process, an information management process, and a performance assessment process.

Mithas et al. (2005) evaluated the impact of CRM on customer knowledge and customer satisfaction and explained that gains in customer knowledge were enhanced when firms share their customerrelated information with their supply chain partners. According to Guenzi and Troilo (2006), marketing-sales integration is a multi-aspect construct made up of various components, which influence different marketing capabilities and highlighted its antecedents and consequences. Donthu et al. (2005) used data envelopment analysis for benchmarking the business activities. Kalaignanam et al. (2008) concentrated on leveraging the Internet for enhancing the efficiency of a business' marketing operations. They presented an organizing framework, which could provide some insights into opportunities for reaching marketing efficiency gains in the context of the interactivity, personalization and addressability characteristics of the Internet.

According to Varadarajan and Yadav (2009) we could expect that marketing strategy and marketing operations would be even more extensively integrated and blended in the Internet-enabled market environment in the future. Rodriguez and Peterson (2012) investigated the role of social CRM and its potential effect on lead generation in business-to-business marketing. Edmiston-Strasser (2009) studied integrated marketing communication in US public institutions of higher education. Caemmerer (2009) discussed different perspectives of integrated marketing communications.

\section{The proposed study}

In this paper, we present an empirical investigation to detect the effects of marketing communications on market share adjustment. The study is concentrated on regular customers who use Irancell services in city of Tehran, Iran. This firm is the second largest mobile service provider in Iran. The proposed study designs a questionnaire in Likert scale consists of 16 questions, distributes it among 185 Iranian experts and analyzes it based on principal component analysis. During the survey, the number questions are reduced to 16 .

Cronbach alpha is calculated as 0.90 and Kaiser-Meyer-Olkin Measure of Sampling Adequacy and Approx. Chi-Square are 0.906 and 2124, respectively. Fig. 1 demonstrates the results of Scree plot. As we can observe from the results of Fig. 1, there are four factors, which could be extracted for further studies. In addition, as we can observe from the results of communalities given in Table 1, most factors are well above the minimum acceptable level of 0.5 . Table 2 demonstrates the results of factor analysis on these factors. 


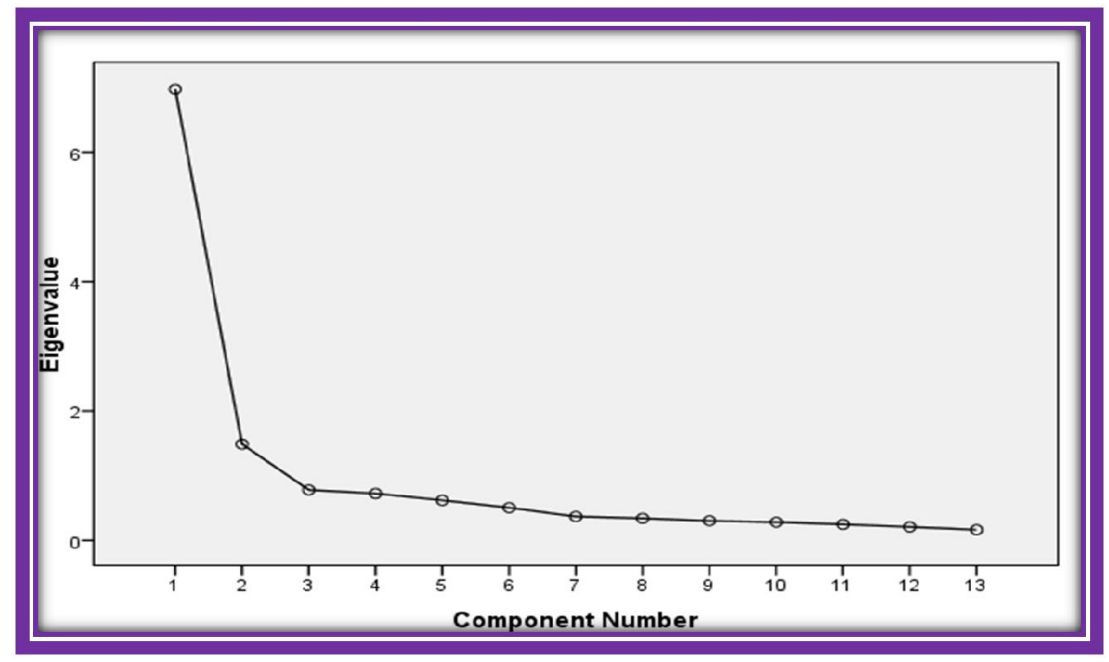

Fig. 1. The Scree plot of different factors

Table 1

The results of communalities

\begin{tabular}{lrr}
\hline & Initial & Extraction \\
\hline VAR00002 & 1.000 & .520 \\
VAR00003 & 1.000 & .784 \\
VAR00004 & 1.000 & .600 \\
VAR00005 & 1.000 & .643 \\
VAR00006 & 1.000 & .651 \\
VAR00008 & 1.000 & .628 \\
VAR00009 & 1.000 & .651 \\
VAR00010 & 1.000 & .627 \\
VAR00011 & 1.000 & .591 \\
VAR00012 & 1.000 & .721 \\
VAR00013 & 1.000 & .630 \\
VAR00014 & 1.000 & .546 \\
VAR00015 & 1.000 & .623 \\
\hline
\end{tabular}

\section{Table 2}

The summary of principal component analysis

\begin{tabular}{|c|c|c|c|c|c|c|c|c|c|}
\hline \multirow{2}{*}{$\begin{array}{r}\text { Compon } \\
\text { ent }\end{array}$} & \multicolumn{3}{|c|}{ Initial Eigenvalues } & \multicolumn{3}{|c|}{ Extraction Sums of Squared Loadings } & \multicolumn{3}{|c|}{ Rotation Sums of Squared Loadings } \\
\hline & Total & $\%$ of Variance & Cumulative \% & Total & $\%$ of Variance & $\begin{array}{c}\text { Cumulative } \\
\%\end{array}$ & Total & $\begin{array}{r}\% \text { of } \\
\text { Variance } \\
\end{array}$ & $\begin{array}{r}\text { Cumulative } \\
\% \\
\end{array}$ \\
\hline 1 & 2.309 & 17.762 & 17.762 & 2.309 & 17.762 & 17.762 & 1.920 & 14.766 & 14.766 \\
\hline 2 & 2.044 & 15.726 & 33.489 & 2.044 & 15.726 & 33.489 & 1.685 & 12.961 & 27.727 \\
\hline 3 & 1.436 & 11.048 & 44.536 & 1.436 & 11.048 & 44.536 & 1.661 & 12.774 & 40.501 \\
\hline 4 & 1.274 & 9.803 & 54.340 & 1.274 & 9.803 & 54.340 & 1.493 & 11.481 & 51.982 \\
\hline 5 & 1.151 & 8.852 & 63.192 & 1.151 & 8.852 & 63.192 & 1.457 & 11.210 & 63.192 \\
\hline 6 & .908 & 6.981 & 70.173 & & & & & & \\
\hline 7 & .778 & 5.982 & 76.155 & & & & & & \\
\hline 8 & .757 & 5.824 & 81.980 & & & & & & \\
\hline 9 & .653 & 5.026 & 87.006 & & & & & & \\
\hline 10 & .520 & 3.999 & 91.005 & & & & & & \\
\hline 11 & .467 & 3.589 & 94.594 & & & & & & \\
\hline 12 & .380 & 2.924 & 97.518 & & & & & & \\
\hline 13 & .323 & 2.482 & 100.000 & & & & & & \\
\hline
\end{tabular}

Based on the results of our survey, we have derived four factors including environment issues, marketing organization, market development and relationship oriented. 


\section{The results}

In this section, we present details of our findings on five influencing factors.

\subsection{The first factor: Environment issues}

The first factor is associated with environment issues and Table 3 demonstrates details of our investigation. As we can observe from the results of Table 3, "Information" is the most important factor, followed by "Motivation", "Perception" and "Power".

Table 3

The summary of factors associated with environment analysis

\begin{tabular}{lcccc}
\hline Option & Factor weight & Eigenvalues & \% of variance & Accumulated \\
\hline Perception & 0.735 & & & \\
Information & 0.844 & 2.489 & 68.223 & 68.223 \\
Motivation & 0.764 & & & \\
Power & 0.720 & & & \\
\hline
\end{tabular}

Cronbach alpha $=0.83$

\subsection{The second factor: Marketing organization}

The second factor is associated with marketing organization and Table 4 shows details of our investigation. As we can observe from the results of Table 4, "Marketing capabilities" is the most important factor, followed by "Optimum advertisement".

\section{Table 4}

The summary of factors associated with marketing organization

\begin{tabular}{lcccc}
\hline Option & Factor weight & Eigenvalues & \% of variance & Accumulated \\
\hline Optimum advertisement & 0.748 & & & \\
Marketing capabilities & 0.766 & 2.039 & 56.766 & 56.766 \\
\hline
\end{tabular}

Cronbach alpha $=0.67$

\subsection{The third factor: Market development strategy}

The third factor is associated with market development strategy and Table 5 shows details of our investigation. As we can observe from the results of Table 5, "General advertisement" is the most important factor, followed by "Sales competitions" and "Product".

Table 5

The summary of factors associated with market development strategy

\begin{tabular}{lcccc}
\hline Option & Factor weight & Eigenvalues & \% of variance & Accumulated \\
\hline Product & 0.663 & & & \\
General advertisement & 0.863 & 2.094 & 66.782 & 66.782 \\
Sales competitions & 0.798 & & & \\
\hline
\end{tabular}

Cronbach alpha $=0.88$

\subsection{The forth factor: Relationship oriented strategy}

The last factor is associated with relationship oriented strategy and Table 6 demonstrates details of our investigation. As we can observe from the results of Table 6, "General administration" is the most important factor, followed by "Internet" and "Direct responsiveness". 
Table 6

The summary of factors associated with relationship oriented strategy

\begin{tabular}{lcccc}
\hline Option & Factor weight & Eigenvalues & \% of variance & Accumulated \\
\hline Internet & 0.780 & & & 38.328 \\
General administration & 0.898 & 1.530 & & 38.328 \\
Direct responsiveness & 0.425 & & & \\
\hline Cronbach alpha $=0.62$ & & & &
\end{tabular}

\section{Conclusion}

This paper has presented an investigation to analyze the effects of marketing communications on market share adjustment. The study aimed on regular customers who used Irancell services in city of Tehran, Iran. The proposed study of this paper has used principle component analysis and it has detected four factors environment issues, marketing organization, market development and relationship oriented. The first factor, environment issues, includes four sub-components where "Information" was the most important factor, followed by "Motivation", "Perception" and "Power". The second factor, marketing organization, also includes three factors where "Marketing capabilities" was the most important factor, followed by "Optimum advertisement". The third factor was associated with market development strategy with two factors where "General advertisement" was the most important factor, followed by "Sales competitions" and "Product". Finally, the last factor was associated with relationship oriented strategy where "General administration" was the most important factor, followed by "Internet" and "Direct responsiveness". We hope the results of our survey could help Irancell service provider to optimize their services.

\section{Acknowledgement}

The authors would like to thank the anonymous referees for constructive comments on earlier version of this paper.

\section{References}

Belch, G. E., Belch, M. A., Kerr, G. F., \& Powell, I. (2008). Advertising and Promotion: An Integrated Marketing Communications Perspective. McGraw-Hill.

Blois, K., \& Ramirez, R. (2006). Capabilities as marketable assets: a proposal for a functional categorization. Industrial Marketing Management, 35(8), 1027-1031.

Caemmerer, B. (2009). The planning and implementation of integrated marketing communications. Marketing Intelligence \& Planning, 27(4), 524-538.

Donthu, N., Hershberger, E. K., \& Osmonbekov, T. (2005). Benchmarking marketing productivity using data envelopment analysis. Journal of Business Research, 58(11), 1474-1482.

Dutta, S., Narasimhan, O. M., \& Rajiv, S. (2005). Conceptualizing and measuring capabilities: methodology and empirical application. Strategic Management Journal, 26(3), 277-285.

Edmiston-Strasser, D. M. (2009). An examination of integrated marketing communication in US public institutions of higher education. Journal of Marketing for Higher Education, 19(2), 142 165.

Eid, R., Trueman, M., \& Ahmed, A. M. (2006). B2B international internet marketing: A benchmarking exercise. Benchmarking: An International Journal,13(1/2), 200-213.

Guenzi, P., \& Troilo, G. (2006). Developing marketing capabilities for customer value creation through Marketing-Sales integration. Industrial Marketing Management, 35(8), 974-988.

Kalaignanam, K., Kushwaha, T., \& Varadarajan, P. (2008). Marketing operations efficiency and the internet: an organizing framework. Journal of Business Research, 61(4), 300-308.

Mithas, S., Krishnan, M. S., \& Fornell, C. (2005). Why do customer relationship management applications affect customer satisfaction?. Journal of Marketing, 201-209. 
174

Payne, A., \& Frow, P. (2005). A strategic framework for customer relationship management. Journal of marketing, 167-176.

Rodriguez, M., \& Peterson, R. M. (2012). The role of social CRM and its potential impact on lead generation in business-to-business marketing. International Journal of Internet Marketing and Advertising, 7(2), 180-193.

Sharma, A., \& LaPlaca, P. (2005). Marketing in the emerging era of build-to-order manufacturing. Industrial Marketing Management, 34(5), 476-486.

Varadarajan, R., \& Yadav, M. S. (2009). Marketing strategy in an internet-enabled environment: A retrospective on the first ten years of JIM and a prospective on the next ten years. Journal of Interactive Marketing, 23(1), 11-22.

Vorhies, D. W., \& Morgan, N. A. (2005). Benchmarking marketing capabilities for sustainable competitive advantage. Journal of Marketing, 69(1), 80-94.

White, T., \& Dieckman, E. (2005). Seizing control of SG\&A. Financial Executive, 21(2), 20-23.

Wilson, H., \& Daniel, E. (2007). The multi-channel challenge: A dynamic capability approach. Industrial Marketing Management, 36(1), 10-20. 